\title{
Global influence of the map of Japan produced by Japanese cartographer Sekisui Nagakubo.
}

\section{MOTOHIRO TSUJIMOTO}

Japan Cartographers Association e-mail; motori-7map@wine.ocn.ne.jp

\begin{abstract}
:
Both epoch-making high accuracy map of Japan named 日本分野図,Nihon bunya zu “Allocation Map of Japan” (Dr.Kazutaka Unno called it as “Astronomical Map of Japan”)compiled by Japanese Cartographer 森幸安 Kouan Mori in 1754,and following, 改正日本輿地路程全図”Kaisei Nihon Yochi Rotei Zenzu “Revised General Route Map of Japan”by 長久保赤水 Sekisui Nagakubo in1779 were created according to the latitude data observed in 14 provinces in Japan recorded in 天文罜統 Tenmon Keitou (book of Astronomy and divination in Japan)written by Japanese astronomer 渋川春海 Harumi Shibukawa. And in 天文瓊統 Tenmon Keitou (book of Astronomy and divination in Japan) the latitude of 北京 Beijing, 南京 Nanjing and 高麗 Korea recorded in 四海験測 Si hăi yān tsē Nationwide survey conducted by 郭守敬 Guo Shoujin et al in1279 in 元 Yuan Dynasty were displayed for revision of calendar to new 授時暦 Shoushi-li calendar. 渋川春海 Harumi Shibukawa adopted 授時暦 Shoushi-li calendar formulated by 郭 守敬 Guo Shoujin et al to his 貞享改暦 Joukyou revision of calendar in Japan 1685. This proves that the technology of observation of the latitude in Japan was transmitted from China for revision of calendar and observed latitude datas recorded in Tenmon Keitou were exploited to the cartography of Map of Japan without land survey project.

In 1754 森幸安 Kouan Mori compiled his 日本分野図,Nihon bunya zu “Allocation Map of Japan” by Chinese technology of 方格図 fānggētu grid map east and west equidistant from the distance of latitude $1^{\circ}$ by Chinese Cartographer 羅洪先 Luo Hong xian’s 廣與図 Guan YuTu, “Vast map of China” in Ming. Kouan Mori improved his map of Japan to realise the particularity in each allocation grid. Kouan Mori learned global atlas from duplicate the Matteo Ricchhi’s 坤輿万国全圖 Kunyu Wanguo Quatu:general map of Myriad countries on the earth 1602.

In 1779, 長久保赤水 Sekisui Nagakubo made many modifications to the Kouan Mori's maps and improve it to carry in pocket, named 改正日本輿地路程全図”Kaisei Nihon Yochi Rotei Zenzu “Revised General Route Map of Japan”and published it. Since 1809, this Nagakubo's map has been repeatedly duplicated and translated into the language of each country in Europe and published, in Russia in 1809 and 1810, in France in 1827 by name of famous Surveyor Krusenstern. In 1855-1862 by United Kingdom Admiralty published the map "Japan Nipon(mean Honshuu Island) Kiusiu and Sikok and a part of coast of Korea" based on a replica map by Krusenstern in 1827. However, these were published without knowing the name of the Japanese original author Sekisui Nagakubo.
\end{abstract}

Keywords: 天文瓊統,Tenmon Keitou 渋川春海 Harumi Shibukawa,森幸安 Kouan Mori, 日本分野図 Nihon bunya zu “Allocation Map of Japan” with grid of latitude line, 長久保赤水 Sekisui Nagakubo, 改正日本輿地路程全図”Kaisei Nihon Yochi Rotei Zenzu “Revised General Route Map of Japan” 郭守敬 Guo Shoujin, 四海験測 Si hăi yān tsē Nationwide survey,羅洪先 Luo Hong xian, (1504-1564). 廣輿図 Guan YuTu, 方格図 fānggētu grid map equidistant from latitude $1^{\circ}$.

\section{Discussion}

\section{Historical technology of calendar and cartography in China.}

In China, observation of latitude was exceeded in nationwide survey 四海験測 Si hăi yān tsē in 1279 for the revision of calendar 宣明暦 Hsuan min-li from 822 to 授時糜 Shoushi-li calendar and objective grasp of nationwide territory simultaneously, conducted by 郭守 敬 Guo Shoujin (1231-1316) and his colleagues in Yuan dynasty.

Chinese technology to confirm latitude from astronomical observation is developed to Chinese cartography of 方格 図 fānggētu grid separate east and west equidistant from latitude $1^{\circ}$ was succeeded from 輿地図 Yu Chidu by 朱 思本 Zhu Si-ben 1321 to 羅洪先 Luo Hong xian's(15041564) 廣與図 Guan YuTu(Wide map of Ming).
2. The observed data of latitude in Japan by Harumi Shibukawa revision of calendar in Joukyou era.

In 1685 Japanese astronomer 渋川春海 Harumi Shibukawa studyed 授時暦 Shoushi-li transmitted from China for revision of calendar from old 宣明暦 Hsuanmin-li calendar 862 in Japan to 授時暦 Shoushi-li calendar. The technology to grasp the nationwide area including surrounding area Matsumae southwest of Hokkaido by observation of latitude for revision of calendar and operated the observation of the latitude in 14 provinces from northern part of Tsugaru in Honshuu Island to Kagoshima city in Kyushuu Island covering mainland of Japan in 1659, and add the latitude data of Ryu-Kyu (Okinawa Island). Harumi Shibukawa reocrded those data in his 天文瓊統,Tenmon Keitou (book of Astronomy and divination in Japan)

Harumi Shibukawa compiled 大和暦 Yamato calendar and Shogunate Government enforce the revision of 
calendar in $2^{\text {nd }}$ year of Joukyou 1685 in Japan called it as 貞享改暦 revision of calendar in Johkyo era..

Keywords: 郭守敬 Guo Shoujin(1231-1316), 改暦 revision of calendar,授時暦 Shoushi-li calendar,四海験 測 Si hăi yān tsē nationwide survey in 1279, 輿地図 Yu Chidu by 朱思本 Zhu Si-ben 1321, 貞享改暦 the revision of calender in Joukyou era.

\section{Application of observed latitude data in} cartography to produce accurate general map of Japan, by citizen without national survey project.

In 1779 長久保赤水 Sekisui Nagakubo made many modifications to the Kouan Mori's 日本分野図,Nihon bunya zu "Allocation Map of Japan" map add description and picture of high way, river, sea way, sea stream and sea tide, stood on domestic user's viewpoint and improve it to carry in pocket useful map, named 改正日本舆地路 程全図”Kaisei Nihon Yochi Rotei Zenzu “Revised General Route Map of Japan” and published it.

We can recognise Sekisui Nagakubo's study of Chinese cartography and Matteo Ricci's Atlas, from Fig6, Fig5.

In Japan there are many mountains and islands and complex terrain, citizen and domestic navigator needed accurate and detailed maps of Japan. In those years, published map of Japan was a simple and inaccurate picture map, such map as Ryuusenzu compiled by Tomonobu Ishikawa. Fig.9

General map of Japan (pictorial map) was compiled from submitted region map across the country more than 5 times from 1591to 1871 by Shogunate Government. And Genaral coastal Map of great Japan (so called Inoh map 伊能図)was compiled in 1821 by national project.

But all of these general maps of Japan were classified as national secrets.

Both Kouan Mori or Sekisui Nagakubo tried to use the observation data of latitude recorded in the astronomy book “Tenmon Keitou 天文椱統”written by astronomer Harumi Shibukawa in 1698 when the calendar was revised. Fig. 1

Each of them estimated the position of the line every 1degree of latitude from the latitude observation data by astronomer Harumi Shibukawa and expressed it on a map, and drew the grid line of longitude estimated with equidistanct to 1 degree of latitude. They divided line of longitude to the west and east at the former capital Kyoto. (example: Imperial Palace 御所 Gosho in Kyoto, DMS Lat $35^{\circ} 01^{\prime} 27^{\prime \prime} \mathrm{N}$, Long135 $45^{\prime} 44^{\prime \prime}$ E. Comparing the distance of longitude $1^{\circ}$ with the distance of latitude $1^{\circ}$ in Kyoto, is approximately $17.7 \%$ less than $1^{\circ}$ latitude distance $(91,274 \mathrm{~m}: 110,949 \mathrm{~m})$.

(But Kouan Mori imagine the length of $1^{\circ}$ latitude as 40 里 $\mathrm{ri}=3927 \mathrm{~m} \times 40=157080 \mathrm{~m}$ )

成都 Chengdu is at $30^{\circ} 04^{\prime} \mathrm{N}$.

Comparing the distance of latitude $1^{\circ}$ with the distance of longitude $1^{\circ}$ in 成都 Chengdu, the distance of longitude $1^{\circ}$ is approximately $13.0 \%$ less than the distance of latitude $1^{\circ}$.

London is at $51^{\circ} 31^{\prime} \mathrm{N}$ latitude.

Comparing the $1^{\circ}$ latitude distance with the $1^{\circ}$ longitude distance in London, $1^{\circ}$ longitude distance is approximately $37.6 \%$ less than $1^{\circ}$ latitude distance.

In the case of Japan or China, it is not a big difference like in London or in northern Europe.

The latitude described in Harumi Shibukawa's 天文瓊統 Tenmon Keitou Astronomy book is based on 365degree, and it same to nationwide survey 四海験測 in 元 yuan.

These values are based on $365^{\circ}, 1.4 \%$ more than modern values based on $360^{\circ}$, and there are also differences due to non-numerical expressions.

\section{Realize national prosperity in national isolation,}

Sekisui Nagakubo folded the small map which became accurate and detailed, and made it portable.

This Sekisui Nagakubo's map has made a strong contribution to Japan's domestic prosperity in not only in national economy but in people's culture, even though national isolation at that time, and has become long-term sales for over a century in Japan.

\section{Realize international reliability as sea map}

Numerical latitude and the lines in this map, and lines temporary representing the longitude are also very useful for foreign navigator. It translated into the language of each country in Russia and Europe, repeatedly duplicated and published. In Europe, the name of the Japanese original author was not written on those maps, but was published under the name of famous explorer Krusenstern, or published under the name of the cartographic office of the admiralty (United Kingdom).

\section{Conclusions}

This high-precision map "Revised General Route Map of Japan" created by Sekisui Nagakubo was used around the world because he took in, fused, and accurately made Chinese technology, European technology of cartography and Japanese geographical knowledge, and returned it to not only domestic but also for the World.

This Nagakubo's “Revised General Route Map of Japan" triggered the creation of the Inoh's complete survey map of the mainland of Japan. With the map by Inoh, Japan was able to defend national land, and diplomatic scramble with United Kingdom not colonized by imperial Russia or so, and realyzed the industrial revolution.

Unknown Japanese original author of "Revised General Route Map of Japan” cartographer Sekisui Nagakubo 長 久保赤水 and tentative map's cartographer 森幸安 Kouan Mori's name should be specified in the crtographer's history of the world from now on with name of cartographer 伊能忠敬 Tadataka Inoh and Rinzou Mamiya 間宮林蔵 who found Channel of 
Mamiya, and 郭守敬 Guo Shoujin in 元 Yuan, 羅洪先 Luo Hong xian or 利瑪竇 Matteo Ricchi in 明 Ming in China, or Korean Cartographer 金正浩 Jon ho Kim. In the case of Far East Orient Asia we can see original unknown development of Cartography.

\section{Chronology in China}

Key word in Chronology

1 .calemdar and cartography 2.latitude 3 . the concept of globe. 4.other chart

1279 元 Yuan 郭守敬 Guo Shoujin 四海験測 Si hăi yān tsē observation of latitude for objective grasp of nationwide territory, and revision of calendar to 授時暦 Shoushi-li calendar

a

1321 元 Yuan 朱思本 Zhu Si-Ben 格子地図 grid map of China based on the distance of Latitude $b$

1555 明 Ming 羅洪先 Luo Hong Xian(1504-1564) 廣興 図 ExpandedGeneral Map (of Ming) b

1595 Abraham Ortelius(Brabantian) published "Japoniae Insvlae Descriptio" Map of Japan partly including middle East Coast of China with scale of latitude North $30^{\circ}, 35^{\circ}, 40^{\circ}$ and longitude east $145^{\circ}-$ $150^{\circ}-145^{\circ}$ by luna distance, not Greenwich (mid atlantic ocean)

d

1602 明 Ming 利瑪竇 Matteo Ricci(1552-1610) from Italy to Macau 1582) the concept of globe

輿地山海全図 Yudi Shanhai Quantu General Map of the Mountain and Sea(geographic), the first edition of Matteo Ricci's World Atlas $\mathrm{c}$

1584 坤興萬國全図 Kunyu Wanguo Quantu :General Map of Myriad Countries on the Earth.1602 c

\section{Chronology in Japan}

1685 Harumi Shibukawa 渋川春海 (1639-1715)

Japanese astronomer adopted Yuan's technology to revise calendar transmitted to Japan by his study, and he operated 貞享改暦 revision of calendar in Joukyou era in Edo era from 宣明暦 Hsuan-Ming-li to 授時暦 Soushi-li, and nationwide observation of latitude in Japan to confirm the distance of geographical position 里差 between China and Japan for revision of new calendar 大和暦 Yamato calendar was operated. * (Cf. Abraham Ortelius's Map of Japan in 1595)

1685 Harumi Shibukawa 渋川春海 wrote 天文瓊統 Tenmon Keitou (book of Astronomy and divination in Japan), with observation data of 14 province in Japan.

1691Tomonobu Ishikawa 日本海山潮陸図 Nihon

Kaizan chou riku zu Map of sea and mountain. sea current and land of Japan (tentative by Tsujimoto) (picture map of Japan)

1701-D year (unknown) Kouan Mori 森幸安

1751 大地圓球天合 三大界五大洲萬國圖 cf. a,b,c,d
Atlas of great circle globe consisted by 3 Worlds and 5 continents and myriad countries. Duplicated from 利瑪䆬 Matteo Ricci's 坤舆萬國全図 Kunyu Wanguo Quantu :General Map of Myriad Countries on the Earth

1754 日本志輿地部 日本分野図 Field allocation map of Japan (Allocation Map of Japan)

1717-1801Sekisui Nagakubo's 長久保赤水 cf. a,b,c,d

1768 Sekisui Nagakubo 改製扶桑分里図 Reproduced allocate by li distsnce ) Map of Japan.

1775 Sekisui Nagakubo 新刻日本興地路程全図 Revised print General road map of Japan.

1780 改正日本輿地路程全図 Revised General Road map of Japan became a century long seller.

1783 大清広輿圖 Dai Shin Kouyozu General map of Great Qin duplicate and revised by Nagakubo. b

1785 地球萬國山海軹地全圖説 around 1788 duplicated and revised by Sekisui Nagakubo.

General map of earth, mountains seas and myriad countries

$<$ Classification of including concept $>$

a. latitude and 授時暦 Shoushi-li calendar.

b. 格子地図 grid map

c. Global Atlas

d. Abraham Ortelius or portlano chart etc.

3.Chronology in Russia and Europe duplicated and translated without original Japanese author's name

(1784 Issac Titsing send Sekisui Nagakubo's "Revised General road map of Japan" to Holland)

1809 Irkutsk

"General Map of showing Japanese Islands and

Neighboring Countries" File in Irkutsk by Baron

Frederiks N.P.Rezanov due to the second mission to Japan in Nadezhda in 1805.

(Allexei V Postnikov wrote)

Shigeru Kobayashi wrote Khvostov or Davidov subordinate of N.P.Rezanov gained it in Sakhalin.

1810 St.Petersburg "General Map of the Japanese Sixty-Six Provinces"in 1810 by Lieutenant Colonel A.I.Khatov .(by Postnikov.)

The representation of direction by Khatov was corrupted. (Tsujimoto)

1827 Krusenstern(from Paris) CARTE de l'empire du "JAPON" 1827

1835 Frantz Von Siebold NIPPON I Third and Fourth distribution from Holland (By Miyazaki)

1855United Kingdom Admiralty “.JAPAN NIPON KYUSIU and SKIKOK and a part of coast of Korea" According to Krusenstern's chart of 1827. Cartographic office of the Admiralty 


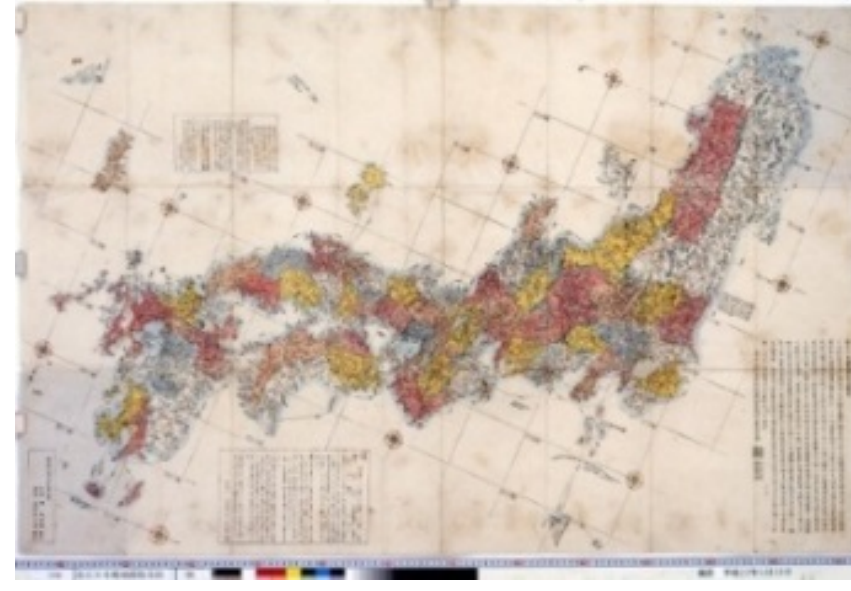

Fig1.Kaisei Nihon Yochi Rotei Zenzu 改正日本輿地 路程全図 Revised Route Map of Japan by Sekisui Nagakubo in 1780 (Takahagi city)

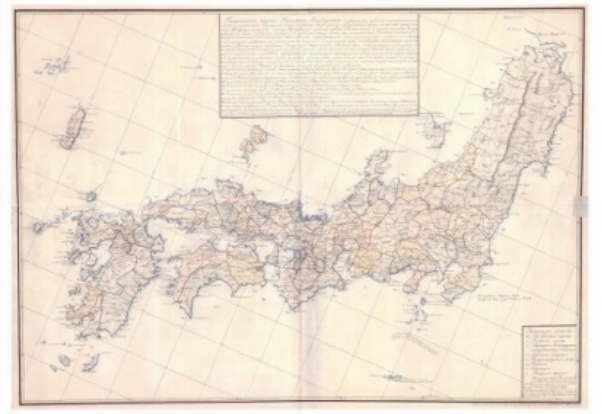

Fig2.General Naya Karta Japonskago 1809 The General map, Showing Japanese Islands and Neighboring Countries Copied from the Japanese File by Baron Frederiks. RGVIA Russia State Military History Archive. (Allexey V Postnikov wrote)(Tsujimoto bought the copy from Vint Print Jan 2015 without description of possetion) Shigeru Kobayashi wrote National Archives of Estonia (Talin) Another is The General map of the Japanese state,Divided into Sixty-Six Provinces, Compiled on the basis of a printed Japanese map in 1810 by Lieutenant Colonel A.I.Khatov. RGVIA (Alexey V Postnikov wrote)

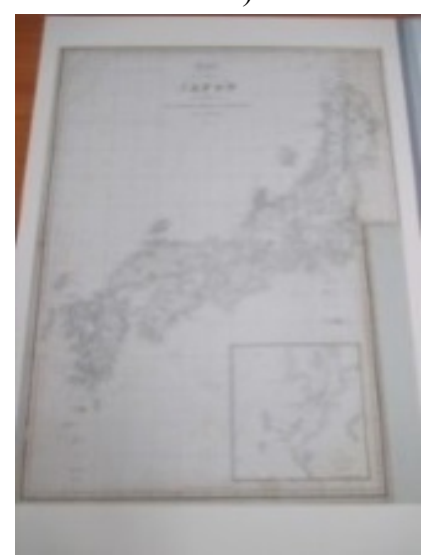

Fig3. CARTE de l'empire du JAPON 1827 By Krusenstern published in France(Kinki University library)

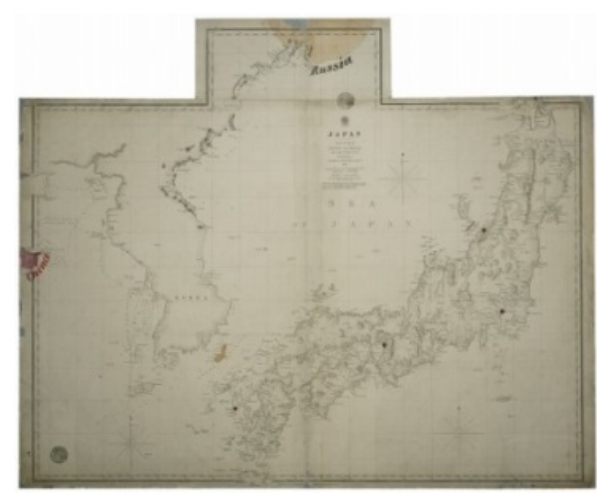

Fig4. .JAPAN NIPON KYUSIU and SKIKOK and a part of coast of Korea

Cartographic office of the Admiralty1855According to Krusenstern's chart of 1827. (United Kingdom Hydro office) .(the bended landform of Tsushima Island in both Krusenstern1827and United Kingdom 1855 was caused by the fold).

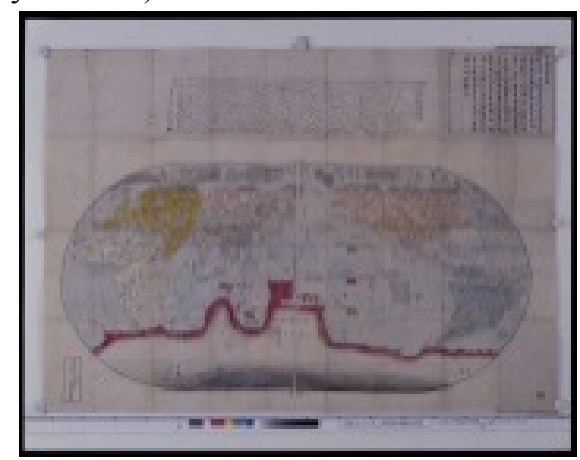

Fig5.地球萬國山海輿地全圖説 around 1788Chikyuu Bankoku Sankai Yochi Zenzu Setsu) By Sekisui Nagakubo 長久保赤水 “General Map of the Myriad Countries, and Mountains and Seas on the earth"

(Tentaive translation by Motohiro Tssujimoto) Kyoto University Library Muroga Collection

Duplicated and revised by Sekisui Nagakubo from 利瑪 竇 Matteo Ricchi's 坤輿萬國全図 Kunyu wanguo Quantu "General Map of Myriad Countries on the earth “,or 輿地山海全図 Yudi Shanhai Quantu Complete Geogrphic "Map of the Mountain and Sea" Chinese rendition of the first edition ofMatteo Ricchi's World map 1584

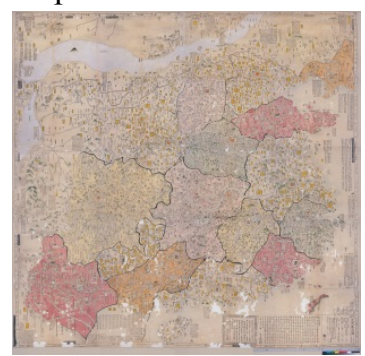

Fig6. 大清広輿圖 Dai Shin Kouyozu around 1783 “General map of Great Qing” by Sekisui Nagakubo 長久保赤水 Ibaraki Prefectural Library. Speculated as edited with reference to multiple Chinese maps applied observation data of latitude and grid. 羅洪先 Luo Hong 
Xian 廣㒹總図 Guangyu zongtu General Map of the expanded Territory of China.

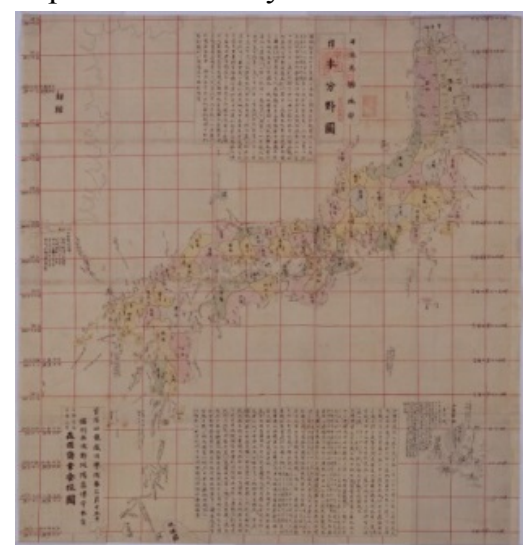

Fig.7 日本分野図 1754 森幸安 Nihon Bunyazu

by Kouan Mori

"Astronomical division Map of Japan". (named in English by Dr.Kazumasa Unno)

"Allocation Map of Japan"

(Tentative name in English by Motohiro Tsujimoto)

(with Latitude grid for explanation including Astronomer Haruumi Shibukawa's 天文分野之圖 Tenmon Bunya no Zu 1677 ) National Archives of Japan

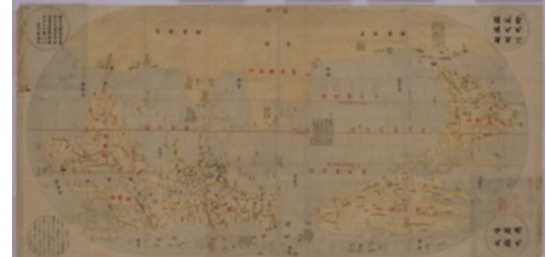

Fig.8 森幸安大地圓球天合 三大界五大洲萬國圖 1748 "Dai chi enkyuu tengou sandaikai godaishuu bankoku zu" Kouan Mori Atlas of great circle globe consisted by 3 Worlds and 5 continents and myriad countries. Duplicated from 利瑪竇 Matteo Ricchi's 坤輿萬國全図

Kunyu Wanguo Quantu : General Map of Myriad Countries on the Earth National Archives of Japan

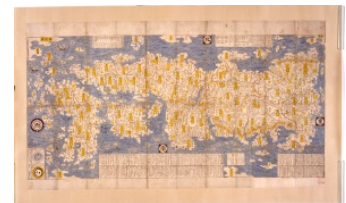

Fig. 9 石川流宣 Moronobu Ishikawa

Map of Japan 日本海山潮陸困 1691

National Museum of Japanese History 
Sekisui Nagakubo producced “Revised General Route Map of Japan” along to the latitude recorded in 天文瓊統 Tenmon Keitou (book of Astronomy and divination in Japan) recorded by Japanese astronomer 渋川春海 Harumi Shibukawa, The latitude data of 対州 Taishuu(対馬 Tsushima Island) $36^{\circ} 30^{\prime} \mathrm{N}$ was declinated too north, Sekisui Nagakubo correct it as $35^{\circ} 45^{\prime} \mathrm{N}$, real latitude of 府中 Fuchuu prefectural government city in 対馬 Tsushima is $34^{\circ} 12^{\prime}$ N. Probably influenced by this error of Tsushima's latitude, the position of 東莱(釜山広域市)Dongnei in Busan city's latitude on Sekisui map is $36^{\circ} 30^{\prime} \mathrm{N}$, almost same to 大田 Daejong city,200km north west from Pusan. 東莱 Dongnei is the ward in Busan where government office of Imperial Korea was located and pair to Embassy office of Japanese Tsushima clan 草梁倭館 Choryang Waegwan.

東莱府 Dongnei Fu and 草梁倭館 Choryang Waegwan was symbol of friendship between Korea and Japan.

This mistake of latitude of Tsushimacalled several sea survey by European countries around Tsushima. An island written 槙 Maki in front of 東莱 Dongnei is 影島 Yeon do.

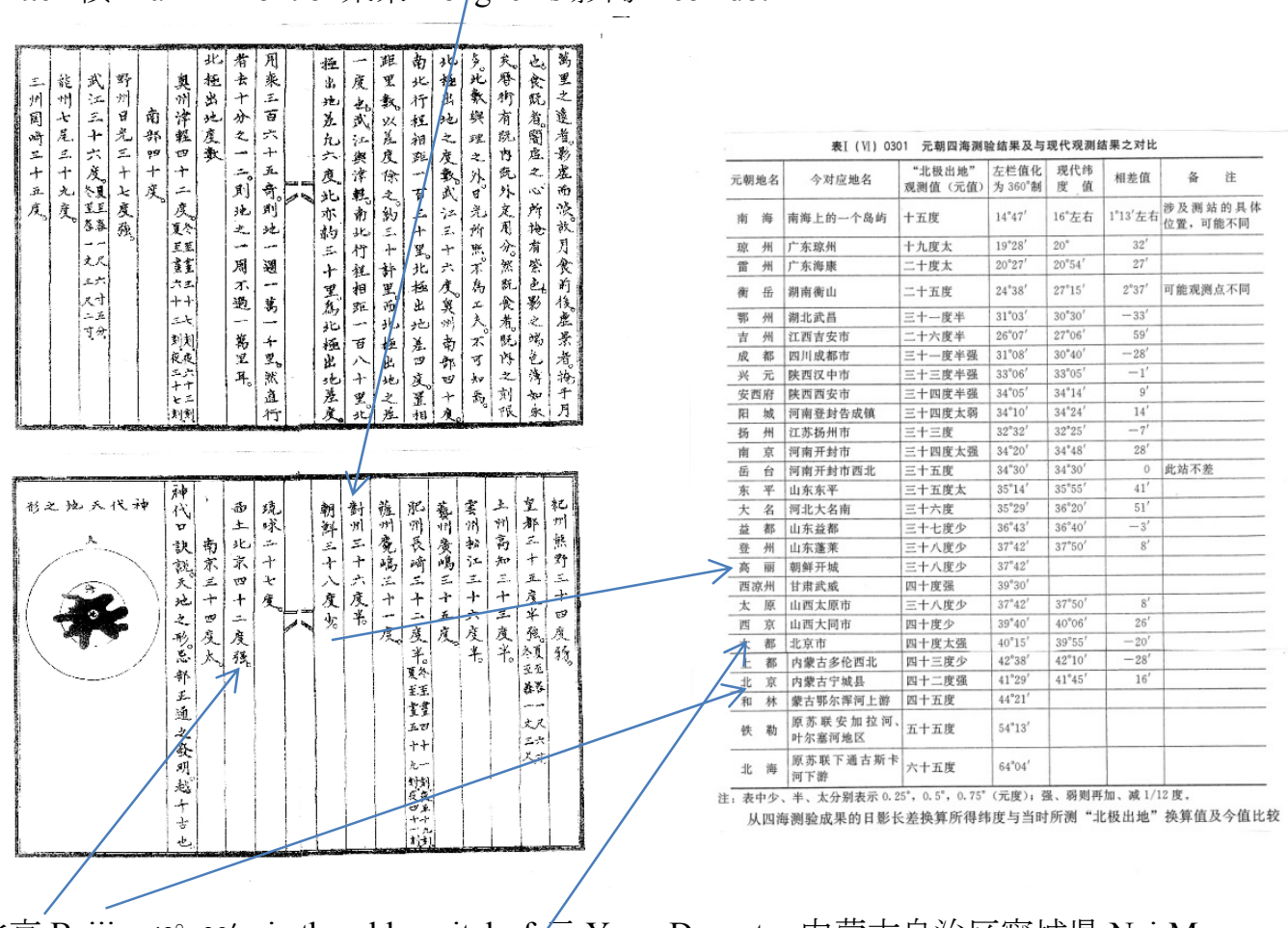

北京 Beijing $42^{\circ} 29^{\prime}$ is the old capital of 元 Yuan Dynasty, 内蒙古自治区寧城県 Nei Menggu Ning county, and that of 北京 Beijing later in the year is 大都 Daydu.

Incidentally, the latitude of 北京 Beijing, 南京 Nanjing and 高麗 Korea were described in the Japanese astronomical book 天文瓊統 Tenmon Keitou (book of Astronomy and divination in Japan) by Harumi Shibukawa is same to the latitude observation data of 四海験測 Si hăi yān tsē Nationwide survey conducted by 郭守敬 Guo Shoujin in1279.

However, 北京 Beijing in the nationwide survey in Yuan China 四海験測 Si hăi yān tsē was the old capital of 元 Yuan Dynasty is 内蒙古自治区寧城県 Nei Menggu Ning county, and that of 北京 Beijing later in the year was 大都 Daydu in 四海験測 Si hăi yān tsē nationwide survey in Yuan China. This is the evidence of traditional technology of latitude from 郭守敬 Guo Shoujin in1279 to Harumi Shibukawa ,Kouan Mori or Sekisui Nagakubo.

Fig10.天文瓊統 Tenmon Keitou (book of Astronomy and divination in Japan)by Harumi Shibukawa 渋川春海 Vol 1.Latitude. p9-p10 Collection of modern historical material III Vol.11 The classic material of Japanese Science and Technology Published by Tosho Shuppan Kagaku Shoin in 2001 Library of National Archives of Japan.

Table1.中国測絵史 1.2 巻 The History of Chinese Surveying and Mapping $1^{\text {st }} 2^{\text {nd }}$ Volume 2002 編揖委員会 Compiling committee of P206 元朝四海測験結果及与現代観測結果之対比 Compare the result of 四海験測 Si hăi yān tsē nationwide survey in Yuan dynasty and result of today's observation. Translated in Japanese by Dr, Ryohei Imamura and castigation by Japan Cartographers Association. 今村遼平訳 日本地図学会校訂 中国地図測量史 2014 


\section{Appendix Necessity of review}

It is impossible to complete the research of historical general map of Japan after 18 century, only by verification of vocabulary or picture as traditional study in literature, without numeric science of cartography. Open science to interdisciplinary research and, open the door to the research by citizen.

\section{Acknowledgement}

I would like to express my gratitude to

Allexei V. Postnikov, Toshihiko Iyemori, Hiroshi Tashiro, Ryohei Imamura, 中国測絵史編集委員会、Committee of compiling The History of Chinese Surveying and Mapping $1^{\text {st }} 2^{\text {nd }}$ Volume, 日本地図学会 Japan Cartographers Association, Dr.Osamu Nishikawa, Yoshihisa Hoshino, Dr.Wang Qianjin, Kazuhiro Uesugi, Yoshihiko Mouri, Prof. Kouichi Shibuya, Haruhisa Sagawa.

\section{References}

1. Kazutaka Unno Cartography in Japan

University of Chicago Press The History of

Cartography Volume Two. Book Two

Cartography in the Traditional East and Southeast Asian

Societies Part Two Cartography in Korean,Japan, and

Vietnam Chapter11

2. Kazuhiko Miyajima Japanese Celestial cartography before the Meiji Period The History of Cartography Volume Two. Book Two Cartography in the Traditional East and Southeast Asian Societies

Part Two Cartography in Korean,Japan,and Vietnam Chapter11

3. Kazuhiro Uesugi Rearrangement of Kouan Mori In history of Cartography 2010.1

4. Allexei V. Postnikov Outline of the History of Russian Cartography pp.44-45

Region: A Prism to View the Slavic-Eurasian World Towards a Discipline of "Regionology"

Internatioal Symposium 1998 Slavic Research Center Hokkaidio University

5. Hiroshi Nakamura The appreciation of Nagakubo Sekisui's map of Japan in European countries: Chiri 地理 Vol.13No.1 .1968 P85-91

6. Translated by Dr. Ryohei Imamura History of Chinese Cartography 中国測絵史 編集委員会編 castigated by the Japan Cartographers Association and 中 国地図情報専門部会 2014

7. Masaaki Nagakubo Compilation of Maps of China and of the World by Sekisui Nagakubo 1971

Kunitada Narumi and Shigeru Kobayashi The Use of Japanese Early Modern Maps by Western

8. Cartographers During the Nineteenth Century 2019

9. Dr.Yoshihisa Hoshino How did it advanced to grasp the topography of the national land of Japan?

About the contribution of the residents in Province of Shimousa and Hitachi. 2014
10. Katsunori Miyazaki: Color Illustration in Frantz Von Siebold's Nipon p18-p21 Shigeru Kobayashi

11. Shigeru Kobayashi and Kunitada Narumi:

The reception of Maps of Japan by Sekisui Nagakubo (1717-1801) Journal of the Japan cartographers

Association

12. Motohiro Tsujimoto: Sekisui Nagakubo's "Kaisei Nihon Yochi Rotei Zenzu "Revised General Route Map of Japan" continued to duplicated and published almost 70 years in Europe.(in Japanese)

Papers and Proceedings of Annual Conference of the Japan Cartographers Association 2017 pp28-29

13. Motohiro Tsujimoto

"East -West Encounter in the Science of Heaven and Earth" Institute for Research in Humanities, Kyoto University. (collection of Kyoto University International Symposium: International conference on traditional sciences in Asia 2017 Oct.27. 2017 )

No.8-2 Analyzing the Early $19^{\text {th }}$ Century Geomagnetic declination $\mathrm{n}$ Japan from Tadataka Inoh Tadataka's Santou-Houi-Ki pp459-465 (in Japanese)

The summary of Supplement to Abstract and Chapter 1.

The observation data of Latitude in Japan recoded Harumi Shibukawa's Tenmon Keitou was utilize to the cartography of Kouan Mori's map or Sekisui Nagakubo's "Revised General Route Map of Japan".

The technology to observe latitude in Harumi Shibukawa's 天文瓊統(Note of astronomy of Japan) was transferred from 四海験測 Nationwide land survey in Yuan dynasty China by 郭守敬 Guo Shoujin.

Therefore Harumi Shibukawa arrange the observation data of 四海験測 nationwide land Survey by 郭守敬 Guo Shoujin in Yuan dynasty China to observation datas in Japan. Sekisui Nagakubo's"Kaisei Nihon Yochi Rotei Zenzu "Revised General Route Map of Japan"was transmitted to Russia and Europe, and repeatedly translated in Russian,French,and English and duplicated without original Japanese author's name Sekisui Nagakubo.

\section{Supplement}

Another purpose of Kouan Mori to produce 日本分野図 Nihon-Bunya-Zu, Allocation Map of Japan was able to describe the particularity in each grid region. 